\title{
Wild Betta fighting fish species in Thailand and other Southeast Asian countries
}

\author{
Bhinyo Panijpan $^{\mathrm{a},+, *}$, Namkang Sriwattanarothai ${ }^{\mathrm{b},+}$, Parames Laosinchai ${ }^{\mathrm{b}}$ \\ a Center of Excellence for Shrimp Molecular Biology and Biotechnology, Faculty of Science, Mahidol \\ University, Bangkok 10400 Thailand \\ b Institute for Innovative Learning, Mahidol University, Nakhon Pathom 73170 Thailand \\ ${ }^{*}$ Corresponding author, e-mail: bhinyop@gmail.com, ${ }^{+}$B. P. and N. S. are co-first authors
}

Received 31 Jul 2020

Accepted 7 Aug 2020

\begin{abstract}
This review updates what is known about Betta fish species in Thailand and Southeast Asian countries. The text is made easy to read for an uninitiated audience. It covers wild nest-builders, wild mouthbrooders, their appearance, distribution, and habitats. A section on domesticated fish is included for the general public. Details for more serious readership can be found in photos, maps, a table, and a diagram. DNA analyses for species differentiation leading to a phylogenetic tree and ancestral relationships are discussed.
\end{abstract}

KEYWORDS: Betta spp., fighting fish, mouthbrooder, bubble-nest builder, species distribution, fish molecular taxonomy

\section{INTRODUCTION}

Ichthyologists know that many species of fish fight with their kinds and others to protect their territories [1-3], but the name fighting fish appears to be mainly attributed to a member of Betta genus, the Siamese fighting fish, Betta splendens Regan, 1910. It has been declared "the national aquatic animal" in 2019 by The National Legislative Assembly of Thailand (NLA). This formal declaration of the fish by the Thai Government may lead to better livelihood for smaller farmers and even high-volume exporters. Mahidol University delegates had contributed significant data, especially DNA analysis, during the three discussion sessions prior to the NLA historical announcement.

Before we describe wild Betta fish, we have to address the domesticated ones first.

\section{DOMESTICATED BETTA FISH}

Most people are familiar with domesticated (not wild-caught) fish bred by farmers and sold in the market for fish lovers both locally and abroad with high volumes. These fish mainly bred from wild $B$. splendens are desired mostly for their attractive appearance, body color and iridescence, fin shape and color pattern, and body size [4-6] (see some domesticated Betta fish in Fig. 1). These are products of careful and diligent breeders from overseas and in Thailand using mainly Mendelian genetics. These efforts often yield hit-and-miss results, but sometimes produce spectacular outcomes.

Our group did the DNA work at the Canadian Centre for DNA barcoding, Guelph, Canada proving that wild $B$. splendens and most of the farmed nestbuilders shown here have basically the same barcoding sequences [7]. Our review of 2010 in this journal was published after the fact.

Naturally, fighters derived mainly from $B$. splendens are also produced nowadays but not as many as the ornamental ones described above (Fig. 1). The fighter has a stout body, short fins, and sharp teeth. Their trained endurance can cause some of them to fight to the death from injuries in gambling dens $[8,9]$. Fighters are generally very hardy and not susceptible to pathogens. However, in general, both farm-bred and wild fish can be infected by parasites, bacteria, and other pathogenic agents [10-12].

\section{NEST BUILDERS AND MOUTHBROODERS}

In Betta fish, there are two separate modes of paternal care for fertilized eggs and young fry [13-15]. The nest-building male parent builds a raft of sticky bubbles shaped like a 3D convex lens, called a nest, on the water surface or underneath the aquatic plant leaves, to deposit newly fertilized eggs into each bubble to take atmospheric oxygen [16-18]. Once the eggs hatch, the male parent would try to retrieve some of the falling fry back into the nest $[19,20]$. Bubble-nest builders prefer stagnant waters [21].

The mouthbrooding male takes fertilized eggs 

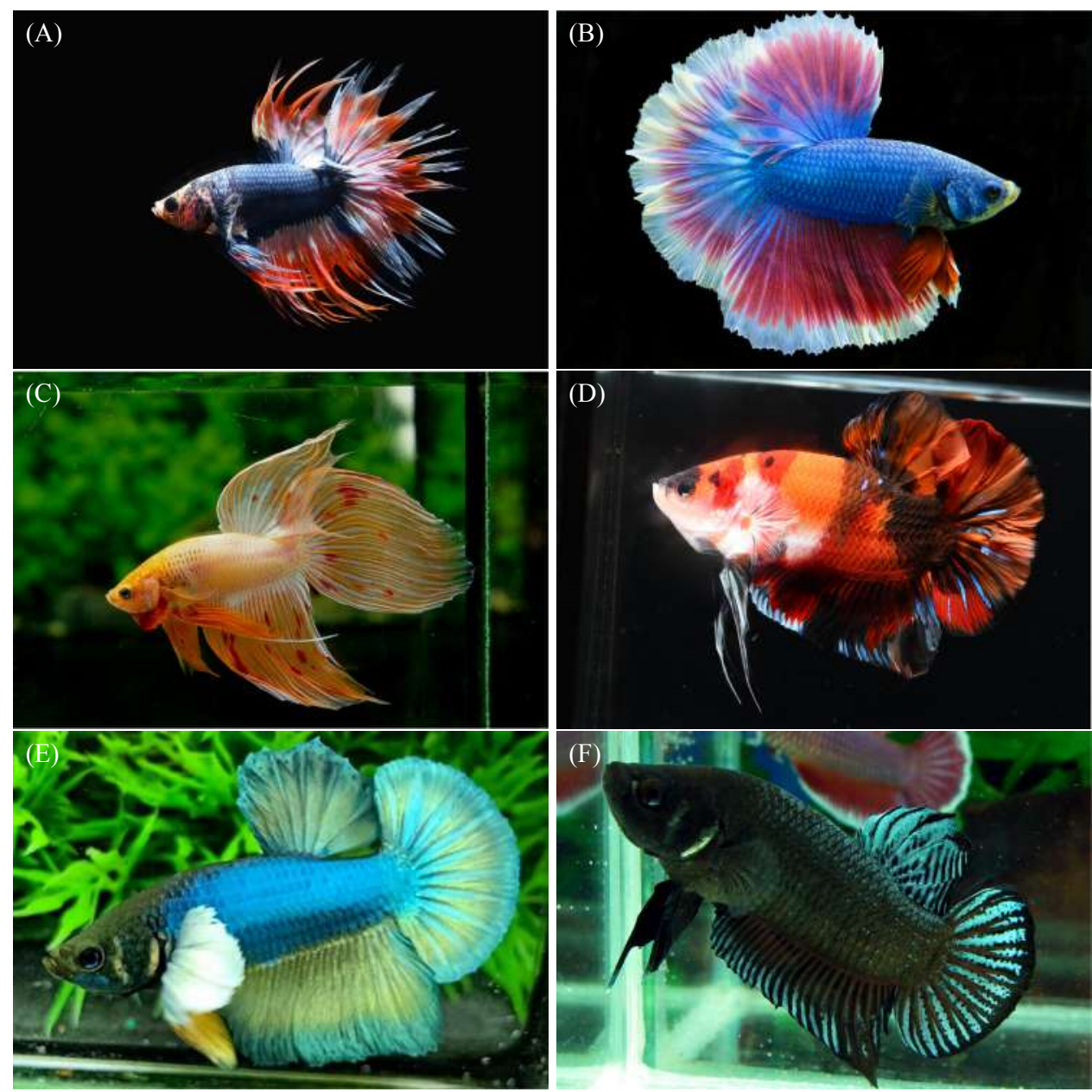

Fig. 1 Examples of domesticated Betta splendens sold in the market nowadays: (A) tricolor crown-tail fish possibly emblematic of flags of Thailand, France, the Netherlands etc.; (B) butterfly halfmoon; (C) veil tail or Pla Kat Jeen; (D) giant Betta (Jumbo); (E) Dumbo short fin; (F) fighter or Pla Kat Mor. The pictures are not of the same scale.

to incubate in the mouth until the hatching stage. Even then, the male parent still keeps their young fry in the mouth for a while before releasing them to swim freely. Brooders prefer running waters, e.g. near waterfalls $[22,23]$. The male nester parent uses the mouth to retrieve fertilized eggs and young hatchlings when it feels danger [17]. They both thus use their mouths in caring for their offspring. As can be seen later, they can evolve from one paternal care type to the other $[15,24]$.

Betta females do not become pregnant after viewing desirable males. They simply produce more eggs that swell the ovary. Fertilization by male sperm occurs outside the female body when eggs are released.

All these freshwater Betta fish have a common feature that is important for their survival in water with low oxygen content [25]: some can even survive in water with near-zero dissolved oxygen. They can gulp air to put molecular oxygen into the labyrinth organ inside the head region. Their distribution in Thailand is shown in Figs. 2 and 3 The nest builders occupy mainly the north and central plains, the upper south, and the west (B. splendens); the northeast (B. smaragdina Ladiges, 1972); the eastern region (B. siamorientalis Kowasupat, Panijpan, Ruenwongsa \& Jeenthong, 2012); the upper and lower southern peninsular Thailand (B. imbellis Ladiges, 1975); and the west of Bangkok, Samut Sakhon Province, and Samut Prakan Province (B. mahachaiensis Kowasupat, Panijpan, Ruenwongsa \& Sriwattanarothai, 2012) [21-23, 26-29]. Recently, large populations of $B$. smaragdina were unexpectedly found in the 


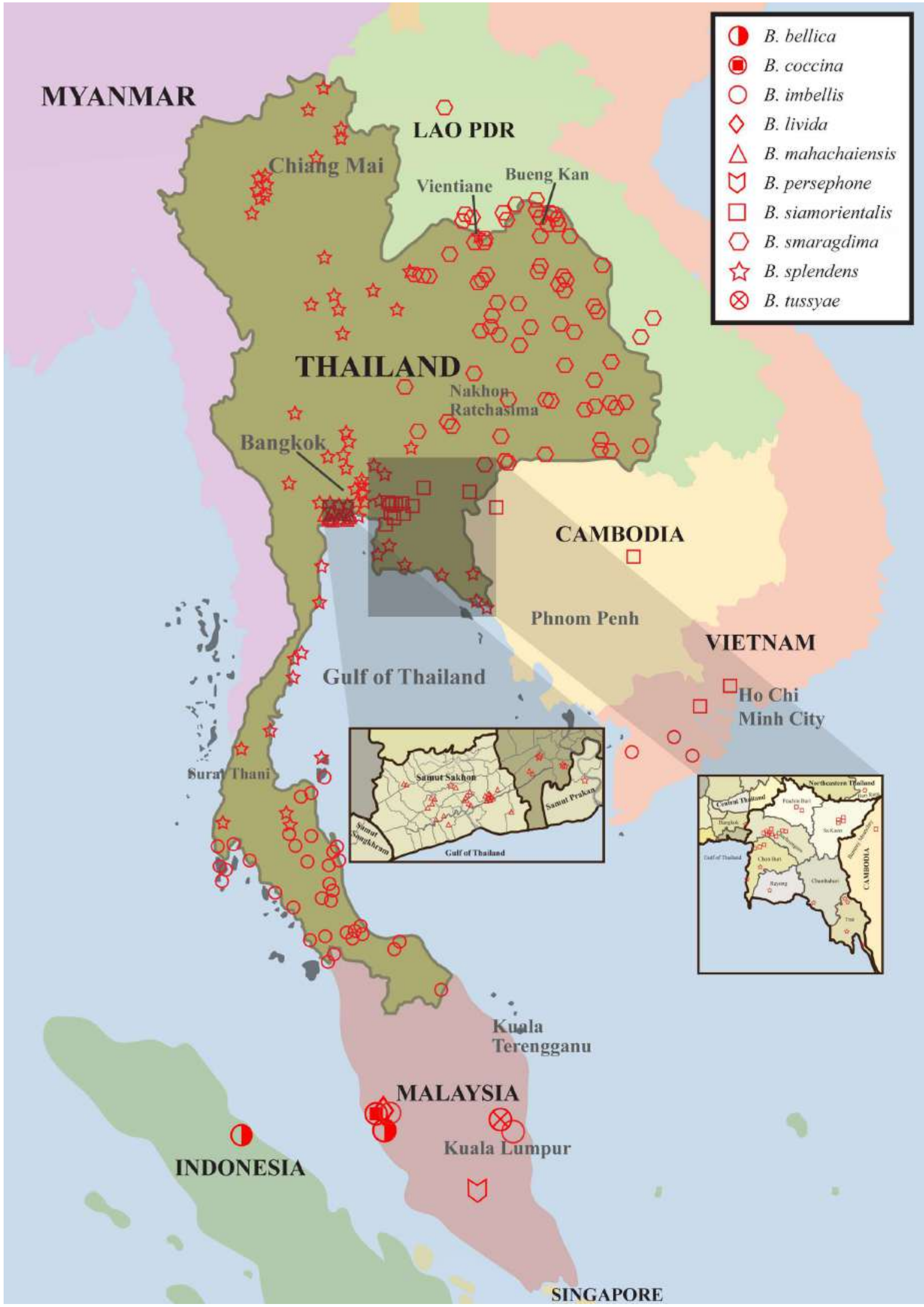

Fig. 2 Distribution of selected nest-building Betta species in Thailand and neighboring countries. 


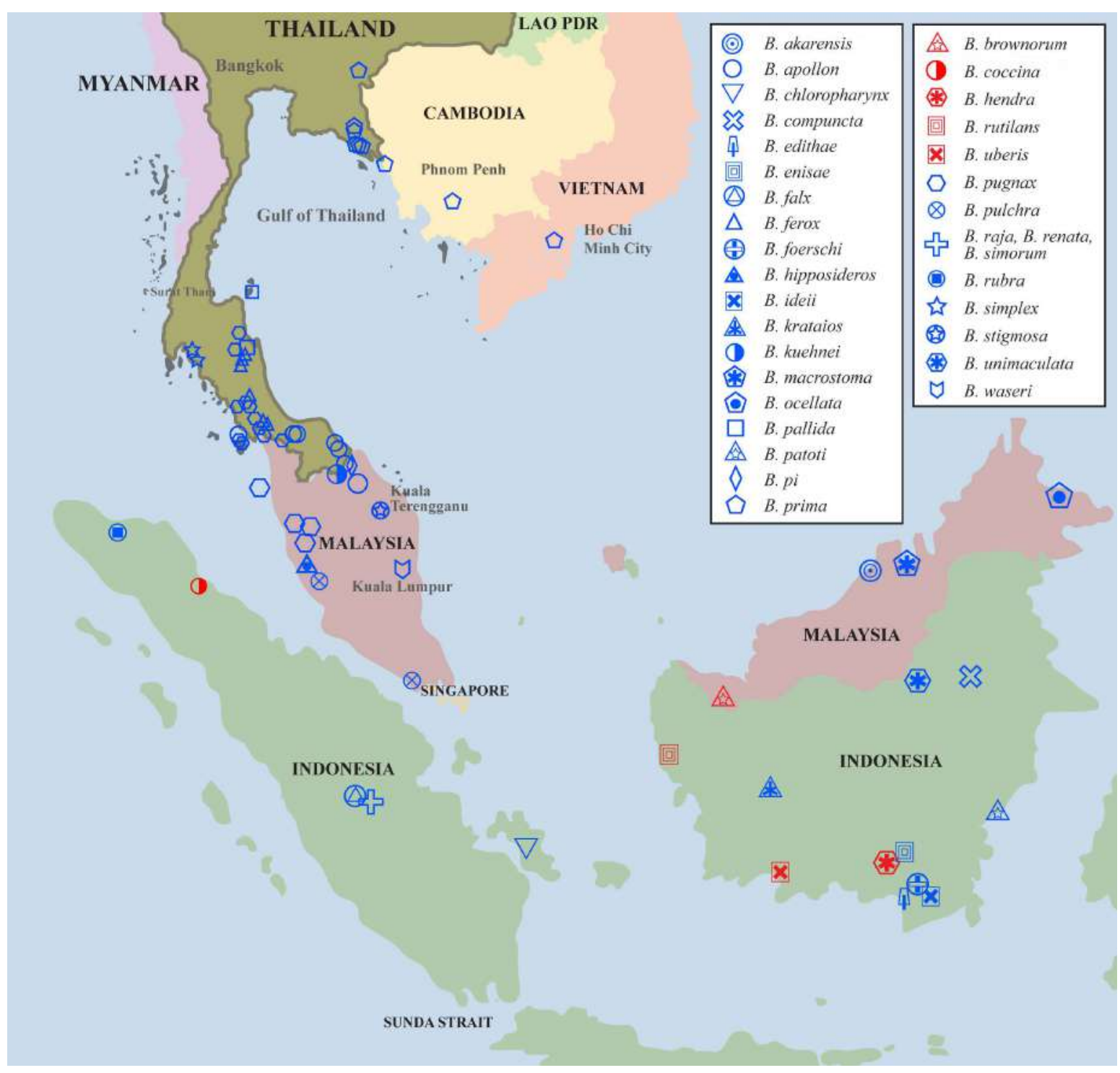

Fig. 3 Distribution of selected wild mouthbrooding Betta species in Thailand and other ASEAN countries. No brooders are found at latitudes above 14.5 degrees north. Wild nesters are also found in Eastern Malaysia and Kalimantan part of the Borneo Island.

south region of Kanchanaburi Province [30].

The brooders are mainly found in the lower southern peninsular Thailand provinces (Fig. 3), including big islands, e.g. Samui and Pa Ngan [22, 29,31]. These fish are found in streams with running water originating from waterfalls, which can be quite a distance away. Incidentally, Thailand has endemic species of the Betta genus, namely the brooders B. simplex Kottelat, 1994, B. pallida Schindler \& Schmidt, 2004, and B. prima Kottelat, 1994, and the nest-builder B. mahachaiensis. Betta prima is found in the eastern region of Thailand.
B. simplex and B. mahachaiensis are subjected to high-volume exports that will push them further into the critically endangered species list $[27,32,33]$.

\section{WILD BETTA FISH IN THAILAND}

Five wild-type nest-building fish in Thailand are very colorful when they, especially males, display their full aggressive posture or stage courtship displays $[8,34-36]$. The body turns dark, fins are unfurled, and colors and color patterns of fins intensify. With the naked eye, some of their external body features of five nest-building Betta in Thailand that are sufficient for differentiating them from one 
Table 1 Comparative table showing, as seen through the naked eye, some external characters of five wild nest-building Betta species of Thailand that sufficiently differentiate one species from another.

\begin{tabular}{|c|c|c|c|c|c|}
\hline Betta species & B. splendens & B. imbellis & B. siamorientalis & B. mahachaiensis & B. smaragdina \\
\hline Opercle & $\begin{array}{l}\text { Two parallel vertical } \\
\text { red bars }\end{array}$ & $\begin{array}{l}\text { Two parallel vertical } \\
\text { iridescent bluish- } \\
\text { green bars }\end{array}$ & $\begin{array}{l}\text { Two parallel vertical } \\
\text { red bars }\end{array}$ & $\begin{array}{l}\text { Two to three parallel } \\
\text { vertical iridescent } \\
\text { bluish-green bars }\end{array}$ & $\begin{array}{l}\text { Multiple iridescent } \\
\text { yellowish-green to } \\
\text { bluish-green plates } \\
\text { or scales }\end{array}$ \\
\hline Caudal fin & $\begin{array}{l}\text { - Bluish-green strips } \\
\text { fanning out from } \\
\text { caudal peduncle } \\
\text { toward posterior } \\
\text { - No black dot } \\
\text { - At least } 50 \% \text { of } \\
\text { red area }\end{array}$ & $\begin{array}{l}\text { - Bluish-green strips } \\
\text { fanning out from } \\
\text { caudal peduncle } \\
\text { toward posterior } \\
\text { - No black dot } \\
\text { - Less than } 20 \% \text { of } \\
\text { red area } \\
\text { - With distal red } \\
\text { crescent and thin } \\
\text { black edge }\end{array}$ & $\begin{array}{l}\text { - Bluish-green strips } \\
\text { fanning out from } \\
\text { caudal peduncle } \\
\text { toward posterior } \\
\text { - No black dot } \\
\text { - Less than 20\% of } \\
\text { red area } \\
\text { - With distal red } \\
\text { crescent and thin } \\
\text { black edge }\end{array}$ & $\begin{array}{l}\text {-Dark strips fanning } \\
\text { out from caudal pe- } \\
\text { duncle toward poste- } \\
\text { rior with bifurcation } \\
\text { - Presence of black } \\
\text { dots flanking stripes }\end{array}$ & $\begin{array}{l}\text {-Dark strips fanning } \\
\text { out from caudal pe- } \\
\text { duncle toward poste- } \\
\text { rior with bifurcation } \\
\text { - Presence of black } \\
\text { dots flanking stripes }\end{array}$ \\
\hline Anal fin & $\begin{array}{l}\text { At least } 40 \% \text { of red } \\
\text { area }\end{array}$ & $\begin{array}{l}\text { About } 5 \% \text { of red at } \\
\text { distal tip }\end{array}$ & $\begin{array}{l}\text { About } 5 \% \text { of red at } \\
\text { distal tip }\end{array}$ & $\begin{array}{l}\text { - Absence of red area } \\
\text { - Blue interradial area }\end{array}$ & $\begin{array}{l}\text { - Absence of red area } \\
\text { - Blue interradial area }\end{array}$ \\
\hline Pelvic fin & $\begin{array}{l}\text { Red-brown to black } \\
\text { and red from } \\
\text { proximal pelvic fin } \\
\text { base to the white tip }\end{array}$ & $\begin{array}{l}\text { Red-brown to black } \\
\text { and red from } \\
\text { proximal pelvic fin } \\
\text { base to the white tip }\end{array}$ & $\begin{array}{l}\text { Red-brown to black } \\
\text { and red from proxi- } \\
\text { mal pelvic fin base to } \\
\text { the white tip }\end{array}$ & $\begin{array}{l}\text { Brown to black with } \\
\text { iridescent green to } \\
\text { bluish-green front } \\
\text { margin and white tip }\end{array}$ & $\begin{array}{l}\text { Brown to black and } \\
\text { red from proximal } \\
\text { pelvic fin base to the } \\
\text { white tip (some } \\
\text { populations having } \\
\text { green to bluish-green } \\
\text { front margin) }\end{array}$ \\
\hline $\begin{array}{l}\text { Body scale and } \\
\text { background }\end{array}$ & $\begin{array}{l}\text { - Scale iridescence } \\
\text { not prominent } \\
\text { - Body background } \\
\text { dark brown }\end{array}$ & $\begin{array}{l}\text { - Scale iridescence } \\
\text { prominent } \\
\text { - Body background } \\
\text { dark brown }\end{array}$ & $\begin{array}{l}\text { - Scale iridescence } \\
\text { prominent } \\
\text { - Body background } \\
\text { black }\end{array}$ & $\begin{array}{l}\text { - Scale iridescence } \\
\text { very prominent } \\
\text { - Body background } \\
\text { black }\end{array}$ & $\begin{array}{l}\text { - Scale iridescence } \\
\text { prominent } \\
\text { - Body background } \\
\text { dark brown }\end{array}$ \\
\hline
\end{tabular}

another are included in Table 1 and Fig. 4. Although our DNA analyses have found no natural hybrids, farm-bred hybrids of these nest-builders are possible. They have the same number of chromosomes $(2 n=42)$ with identical karyotype [37-39], our unpublished results.

The total lengths of $B$. splendens, $B$. mahachaiensis, and a typical $B$. smaragdina are very similar $(3.7-4 \mathrm{~cm})$, whereas those of $B$. imbellis and $B$. siamorientalis are also similar, but shorter $(2.7-3 \mathrm{~cm})$ than the other three above $[13,26]$. The farm-bred ones may become longer eventually.

The bodies and fins of mouthbrooders are usually dull in color, mostly brown with darker stripes, making it difficult for the untrained eye to distinguish one species from another [23]. One exception is $B$. simplex, which has a beautiful pattern on its anal fin and caudal fin (Fig. 5).

\section{WILD BETTA FISH IN OTHER ASEAN COUNTRIES}

Thailand is not the only country harboring the wild Betta fish species. Cambodia, Lao PDR, Vietnam, east and west Malaysia, and Indonesia islands, especially Borneo, also have native wild species [23, 29]. There are no reports of wild fish of this genus in Myanmar and the Philippines. In fact, outside of the
ASEAN countries mentioned above, no wild Betta fish are found. China has no native wild Betta fish. Pla Kat Jeen (China fighting fish) is called that because their fins are longer than usual, making them appear like Chinese opera characters wearing long loose clothing.

The upper peninsular Malaysia provinces share common species of both types of paternal care with those in lower peninsular Thailand (Figs. 2 and 3). Cambodia, Lao PDR, and Vietnam have Betta nestbuilding fish; some are common to those of Thailand [29]. Surprisingly, estuarial south Vietnam has $B$. imbellis identical with those of southern peninsular Thailand and Malaysia. As mentioned above, eastern coastal Thailand has a wild mouth brooder species, B. prima, living along mountain streams (running water), whereas similar-looking wild mouthbrooders in south Vietnam live in paddy fields (stagnant water) (Fig. 3).

Wild Betta species in Southeast Asia occupy a variety of habitats: from fresh to brackish; from alkaline to acidic; from transparent to translucent; and even dark brown waters of the peat swamp [23,29]. Not all Betta species are small. Some wild Betta are quite large. For example, the brooder B. pi Tan, 1998's total length is about $12-14 \mathrm{~cm}$ and that of the nester $B$. bellica Sauvage, 

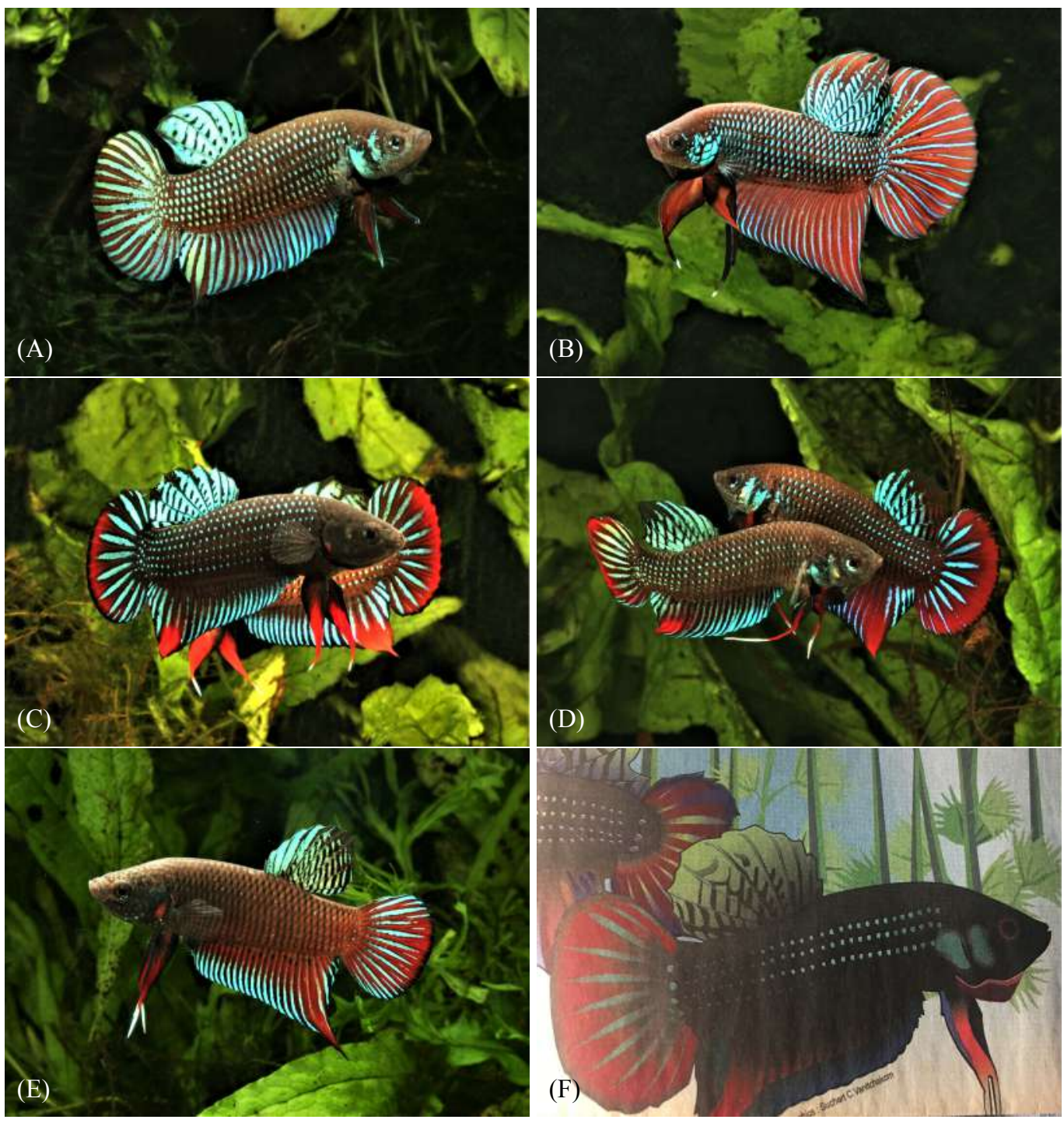

Fig. 4 Photos of the five fully-grown and fully-aggressive male nest-builders in Thailand: (A) B. mahachaiensis; (B) B. smaragdina; (C) B. siamorientalis; (D) B. imbellis; (E) B. splendens; (F) a modified photo of the wild-caught Betta from Nakhon Si Thammarat Province mistaken for B. splendens in a publication by its authors [35].

1884 is about 7-8 cm. Some fish from Borneo can be quite colorful, e.g. B. albimarginata Kottelat \& Ng, 1994 (mouthbrooder), B. macrostoma Regan, 1910 (mouthbrooder), B. rubra Perugia, 1893 (mouthbrooder), and B. coccina Vierke, 1979 (nestbuilder).

Geological evidence shows that in the last Ice Age, about 20000 years ago, the Gulf of Thailand was dry [40]. Betta fish might have been spreading and evolving among Southeast Asian countries, namely Thailand, Vietnam, Malaysia, and Indonesia, through freshwater rivers running along the Gulf of Thailand, the Sunda Strait, and Borneo [24].

\section{ROLE OF SHORT PIECES OF MITOCHONDRIAL AND NUCLEAR DNA IN DIFFERENTIATING BETTA SPECIES}

Up to now, most taxonomic works on Betta fish have been based on morphological criteria in grouping them accordingly. Past attempts using random amplified polymorphic DNA (RAPD) analysis have not been satisfactory [41].

Our group started using a more sophisticated mitochondrial DNA barcoding (based on cytochrome $c$ oxidase subunit I, COI) and $16 \mathrm{~S}$ ribosomal DNA (16S rDNA), together with the nuclear gene ITS1 (ribosomal internal transcribed 

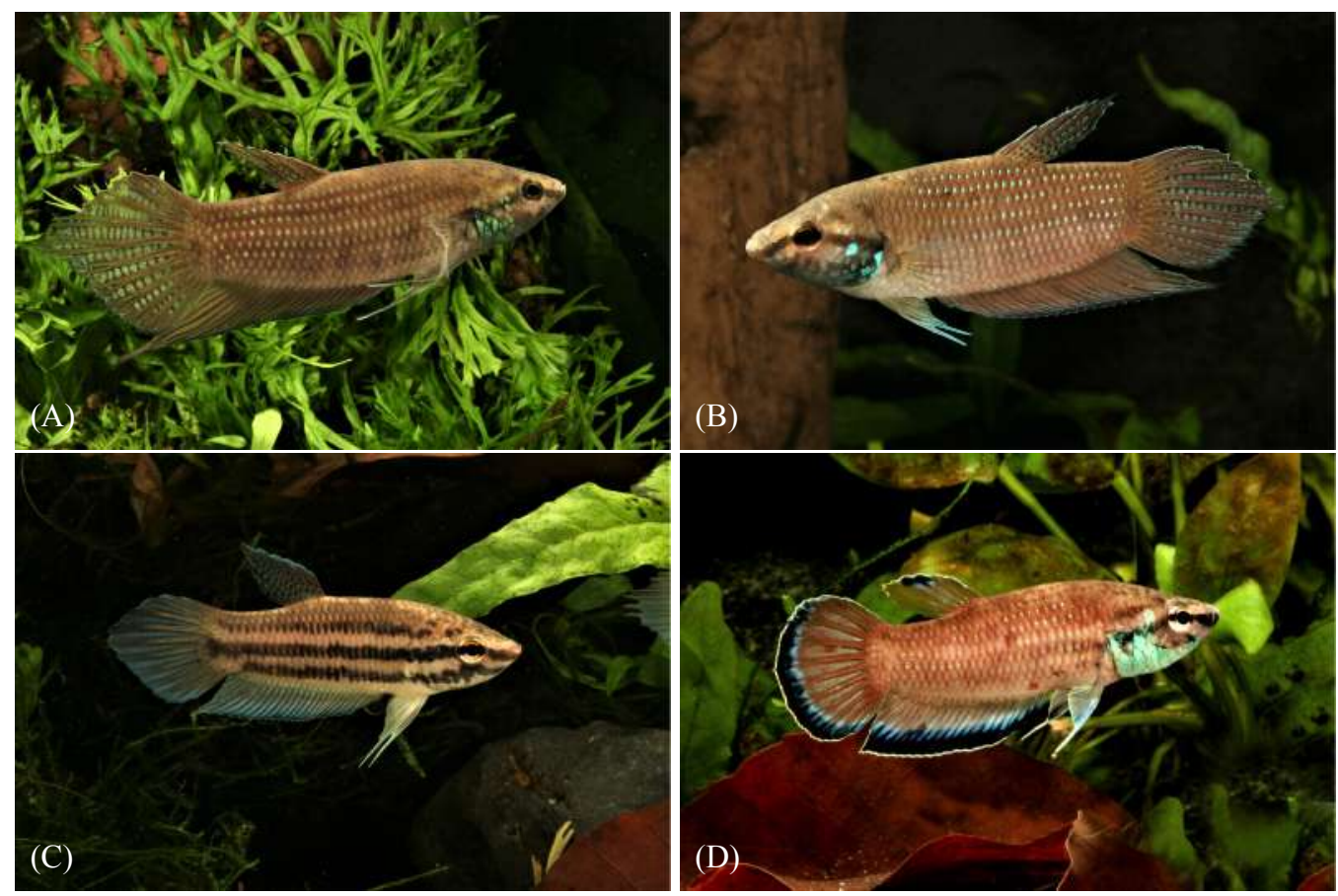

Fig. 5 Photos of the four fully-grown and fully-aggressive male mouthbrooders in Thailand: (A) B. apollon; (B) B. ferox; (C) B. prima; (D) B. simplex.

spacer 1 ), to successfully identify $B$. mahachaiensis and $B$. siamorientalis (both nest builders of Thailand) as new species $[7,26,27]$. Another application is using DNA analyses to put the fish in their groupings, which turn out to correspond very well with those for fish of similar appearances of both types as shown in Fig. 6. Moreover, our DNA analyses show that eastern Thailand $B$. prima is identical with $B$. pallida, and the same for southern brooders B. apollon Schindler \& Schmidt, 2006 and B. ferox Schindler \& Schmidt, 2006 [31]. The number of valid Betta species is not definite because a few brooder pairs with different species names are suspected to be the same by evidence based on DNA analysis (B. pallida vs B. prima and B. apollon vs $B$. ferox) as well as their dubious morphological differences (B. rubra vs B. dennisyongi Tan, 2013). By the way, $B$. dennisyongi and B. omega Tan \& Ahmad, 2018 (both brooders) are two latest additions to the previous list of species $[42,43]$.

\section{MOLECULAR ANCESTRAL RELATIONSHIP}

Another result of working with mitochondrial COI is that we reconstructed ancestral relationships among the nest-builders and brooders whose COI sequences were available for analysis. One interesting finding is that Betta fish could switch from one type of paternal care to the other (Fig. 6) [15, 24]. Another finding is that some species differentiation, especially that for the B. smaragdinas in the northeast of Thailand, corresponds to the timeline of geographical shifts of terrains. The estimated timeline for the northeastern "speciation" coincides well with the eastward tilt of the northeastern plateau causing the Chi and Mun rivers to flow eastward, opposite to their previous direction [44]. Two important basins (Korat and Sakon Nakhon) were likely created by this geobiological event.

\section{FUTURE RESEARCH}

After more than a decade researching Betta fish, we wish to suggest two research venues to exploit DNA technology to enhance the beauty and reduce aggressive behavior. Complete mitochondrial genome sequences of the bubble-nesters (B. splendens and $B$. mahachaiensis) and the mouthbrooders (B. apollon, B. pi, and B. simplex) have now been published [45-48].

(A) Exploiting molecular techniques to produce fish with desirable traits for fish lovers, for example fish pigment distribution on the body, fin shape, and body size [49-52], with more precise outcomes, unlike the present practice of hit-and-miss Mendelian genetics. 


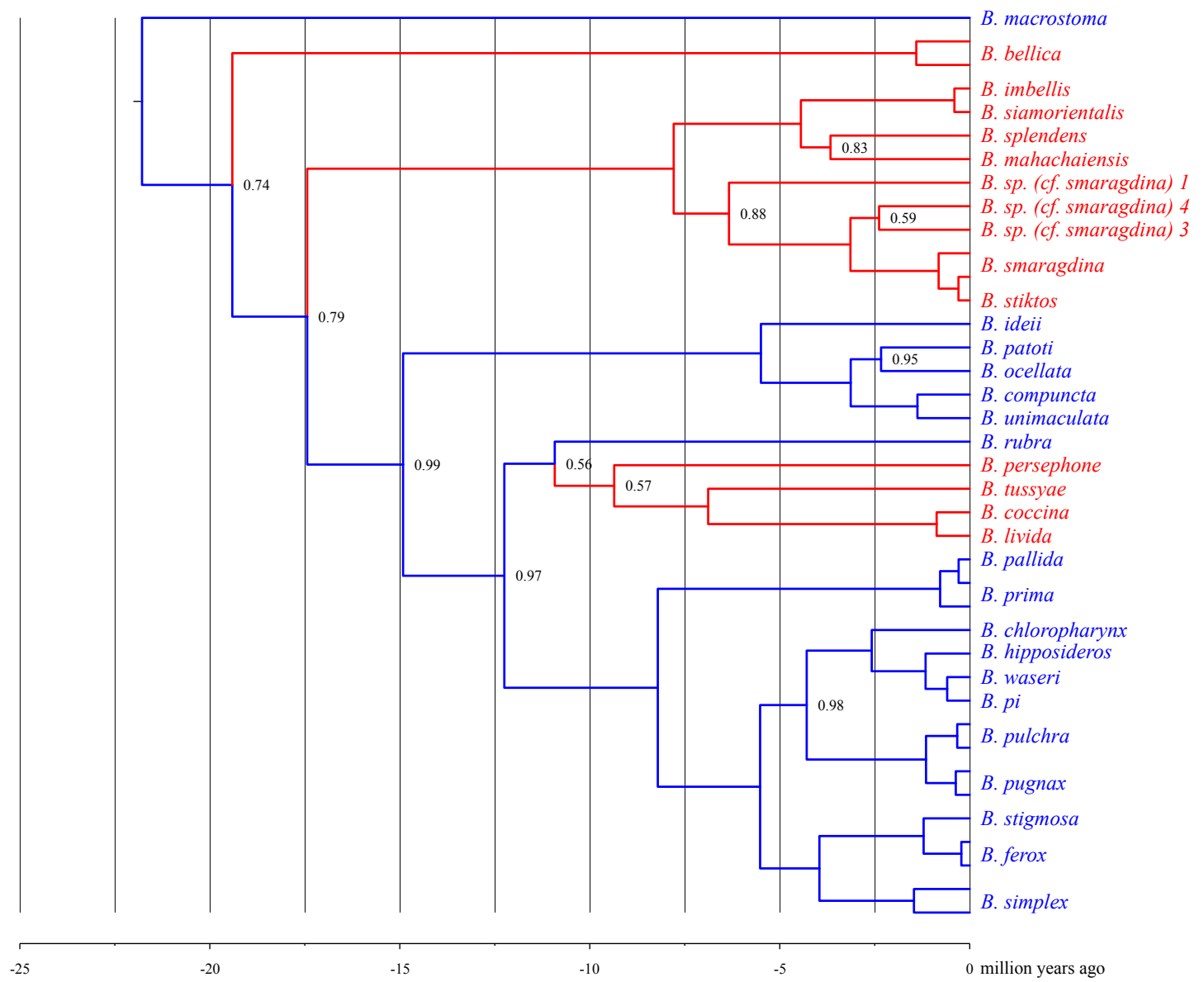

Fig. 6 The phylogenetic tree of selected Betta fishes reconstructed from their COI sequences. Reds indicate nest-building parental-care type while blues signify mouthbrooding one. Estimated speciation times can be read from the scale at the bottom. The numbers at some speciation nodes indicate the probabilities that the corresponding groupings are correct while those without any number are practically certain.

(B) Pinpoint Betta genes that are responsible for their aggressiveness with the aim of eventually reducing aggressive tendencies without affecting their essential behaviors such as courtship. Normally a litter of fish growing up together does no fight; they have their pecking orders. Nonetheless, fish from various sources will fight when put in the same tank. This kind of work may lead to suppressing aggressive tendencies in other animals including humans. Researchers have found hormones and neurotransmitters in fish that correspond to those found in higher animals $[53,54]$. Perhaps exploiting CRISPR technology may help.

We have observed different degrees of aggressiveness among domesticated Betta fish populations, long-finned and short-finned alike. Perhaps these can be used to study genes responsible for differential aggressive behavior.

\section{RESOURCES FOR POPULAR EASY-TO-READ INFORMATION}

1. International Betta Congress (IBC) website, www. ibcbettas.org; 2. Horst Linke's Book [22]; 3. Betta handbook [6]; 4. Thai website "Taiwod", www. taiwod.com.

Acknowledgements: We are indebted to two special persons who played crucial roles in getting us started on fish research: Mr. Atison Phumchoosri and Mr. Horst Linke. They introduced us to the problem of the Mahachai fish and to the barcoding group in Canada. We are grateful to Ms. Sirinut Chimplee (farmed fish) and Mr. Horst Linke (wild fish) for their permission in using their photographs. Fish are named by the authors of the photographs. Thanks are also due to Ms. Jiraporn Thanpaew for the maps. 


\section{REFERENCES}

1. Miller RJ, Miller HC (1969) Studies on agonistic behavior of anabantoid fishes. Proc Okla Acad Sci 49, 60-85.

2. Meliska CJ, Meliska JA, Peeke HVS (1980) Threat displays and combat aggression in Betta splendens following visual exposure to conspecifics and oneway mirrors. Behav Neural Biol 28, 473-486.

3. Tooker CP, Miller RJ (1980) The ontogeny of agonistic behaviour in the blue gourami, Trichogaster trichopterus (Pisces, Anabantoidei). Anim Behav 28 973-988.

4. Na Ayudhya P (2001) Secret Recipes for Raising and Propagating Siamese Fighting Fish, Naew Kasetagum Publishers, Bangkok. [in Thai]

5. Tlusty M (2002) The benefits and risks of aquacultural production for the aquarium trade. Aquaculture 205, 203-219.

6. Goldstein RJ (2015) The Betta Handbook, Barron's, Hauppauge.

7. Sriwattanarothai N, Steinke D, Ruenwongsa P, Hanner R, Panijpan B (2010) Molecular and morphological evidence supports the species status of the Mahachai fighter Betta sp. Mahachai and reveals new species of Betta from Thailand. J Fish Biol 77, 414-424.

8. Simpson MJA (1968) The display of the Siamese fighting fish, Betta splendens. Anim Behav Monogr 1, $1-73$.

9. Verbeek P, Iwamoto T, Murakami N (2008) Variable stress-responsiveness in wild type and domesticated fighting fish. Physiol Behav 93, 83-88.

10. Puttinaowarat S, Thompson KD, Kolk A, Adams A (2002) Identification of Mycobacterium spp. isolated from snakehead, Channa striata (Fowler), and Siamese fighting fish, Betta splendens (Regan), using polymerase chain reaction-reverse cross blot hybridization (PCR-RCBH). J Fish Dis 25, 235-243.

11. Senapin S, Phiwsaiya K, Laosinchai P, Kowasupat C, Ruenwongsa P, Panijpan B (2014) Phylogenetic analysis of parasitic trematodes of the genus Euclinostomum found in Trichopsis and Betta fish. J Parasitol 100, 368-371.

12. Dong HT, Senapin S, Phiwsaiya K, Panijpan B (2018) Histopathology and culturable bacteria associated with "big belly" and "skin nodules" syndromes in ornamental Siamese fighting fish, Betta splendens. Microb Pathog 122, 46-52.

13. Witte K, Schmidt J (1992) Betta brownorum, a new species of anabantoids (Teleostei; Belontiidae) from northwestern Borneo, with a key to the genus. Ichthyol Explor Freshw 2, 305-330.

14. Britz R (2001) The genus Betta-monophyly and intrarelationships, with remarks on the subfamilies Macropodinae and Luciocephalinae (Teleostei: Osphronemidae). Ichthyol Explor Freshw 12, 305-318.
15. Rüber L, Britz R, Zardoya R (2006) Molecular phylogenetics and evolutionary diversification of labyrinth fishes (Perciformes: Anabantoidei). Syst Biol 55, 374-397.

16. Jaroensutasinee M, Jaroensutasinee K (2001) Bubble nest habitat characteristics of wild Siamese fighting fish, Betta splendens. J Morphol 60, 103-125.

17. Rüber L, Britz R, Tan HH, Ng PKL, Zardoya R (2004) Evolution of mouthbrooding and life-history correlates in the fighting fish genus Betta. Evolution 58, 799-813.

18. Kang CK, Lee TH (2010) The pharyngeal organ in the buccal cavity of the male Siamese fighting fish, Betta splendens, supplies mucus for building bubble nests. Zool Sci 27, 861-866.

19. Braddock JC, Braddock ZI (1959) The development of nesting behaviour in the Siamese fighting fish Betta splendens. Anim Behav 7, 222-232.

20. Bronstein PM (1982) Breeding, paternal behavior, and their interruption in Betta splendens. Anim Learn Behav 10, 145-151.

21. Lertpanich K, Aranyavalai V (2007) Species diversity, distribution and habitat characteristic of wild bubble nesting betta (Betta spp.) in Thailand. KMITL Sci J 7, 37-42.

22. Linke H (2014) Labyrinth Fish World, Best View Fish Magazine Taiwan, Taiwan.

23. Monvises A, Nuangsaeng B, Sriwattanarothai N, Panijpan B (2009) The Siamese fighting fish: Wellknown generally but little-known scientifically. Sci Asia 35, 8-16.

24. Laosinchai P, Panijpan B (2019) Phylogeography of Betta and Trichopsis (Perciformes: Osphronemidae) fighting fishes in Thailand and neighboring countries. Thailand Nat Hist Mus J 13, 135-153.

25. Tate M, McGoran RE, White CR, Portugal SJ (2017) Life in a bubble: the role of the labyrinth organ in determining territory, mating and aggressive behaviours in anabantoids. J Fish Biol 91, 723-749.

26. Kowasupat C, Panijpan B, Ruenwongsa P, Jeenthong $T$ (2012) Betta siamorientalis, a new species of bubble-nest building fighting fish (Teleostei: Osphronemidae) from eastern Thailand. Vertebr Zool 62, 387-397.

27. Kowasupat C, Panijpan B, Ruenwongsa P, Sriwattanarothai N (2012) Betta mahachaiensis, a new species of bubble-nesting fighting fish (Teleostei: Osphronemidae) from Samut Sakhon Province, Thailand. Zootaxa 3522, 49-60.

28. Kowasupat C, Panijpan B, Laosinchai P, Ruenwongsa P, Phongdara A, Wanna W, Senapin S, Phiwsaiya $\mathrm{K}$ (2014) Biodiversity of the Betta smaragdina (Teleostei: Perciformes) in the northeast region of Thailand as determined by mitochondrial COI and nuclear ITS1 gene sequences. Meta Gene 2, 83-95.

29. Panijpan B, Sriwattanarothai N, Kowasupat C, Ruenwongsa P, Jeenthong T, Phumchoosri A (2017) Biodi- 
versity of bubble-nest building and mouth-brooding fighting fish species of the genus Betta in Southeast Asia. Thailand Nat Hist Mus J 11, 1-21.

30. Pammanasut P, Panijpan B, Senapin S, Ruenwongsa P, Sriwattanarothai N, Laosinchai P, Phiwsaiya K (2018) Discovery of wild populations of Betta smaragdina Ladiges, 1972 (Teleostei, Osphronemidae) in a western province of Thailand. Check List 14, 1077-1082.

31. Panijpan B, Kowasupat C, Laosinchai P, Ruenwongsa P, Phongdara A, Senapin S, Wanna W, Phiwsaiya $\mathrm{K}$, et al (2014) Southeast Asian mouth-brooding Betta fighting fish (Teleostei: Perciformes) species and their phylogenetic relationships based on mitochondrial COI and nuclear ITS1 DNA sequences and analyses. Meta Gene 2, 862-879.

32. Vidthayanon C (2005) Thailand Red Data: Fishes, Office of Natural Resources and Environmental Policy and Planning, Bangkok.

33. Vidthayanon C (2013) Betta simplex. The IUCN Red List of Threatened Species 2013: e.T2777A9479973, International Union for Conservation of Nature and Natural Resources, Bangkok.

34. Jaroensutasinee M, Jaroensutasinee K (2001) Sexual size dimorphism and male contest in wild Siamese fighting fish. $J$ Fish Biol 59, 1614-1621.

35. Jaroensutasinee M, Jaroensutasinee K (2003) Type of intruder and reproductive phase influence male territorial defence in wild-caught Siamese fighting fish. Behav Process 64, 23-29.

36. Clotfelter ED, Curren LJ, Murphy CE (2006) Mate choice and spawning success in the fighting fish Betta splendens: the importance of body size, display behavior and nest size. Ethology 112, 1170-1178.

37. Ratanatham S, Patinawin S (1979) Cytogenetic studies of Siamese fighting fish (Betta splendens Regan). J Sci Soc Thailand 5, 17-26.

38. Magtoon W, Rangsiruji A, Donsakul T (2007) Karyotypes of Betta splendens, B. prima, Trichopsis vittatus and Trichogaster trichopterus (family Belontiidae) from Thailand. In: Proc of the 33rd Congress on Science and Technology of Thailand, Walailuk Univ.

39. Grazyna F-S, Fopp-Bayat D, Jankun M, Krejszeff S, Mamcarz A (2008) Note on the karyotype and NOR location of Siamese fighting fish Betta splendens (Perciformes, Osphronemidae). Caryologia 61, 349-353.

40. Sathiamurthy E, Voris HK (2006) Maps of Holocene sea level transgression and submerged lakes on the Sunda Shelf. Nat Hist J Chulalongkorn Univ 2, 1-44.

41. Tanpitayacoop C, Na-Nakorn U (2005) Genetic variation of Betta spp. in Thailand by random amplified polymorphic DNA (RAPD) method. In: Proc of the 43rd Kasetsart Univ Annual Conference, pp 185-192.

42. Tan HH (2013) The identity of Betta rubra (Teleostei: Osphronemidae) revisited, with the description of a new species from Sumatra, Indonesia. Raffles Bull Zool 61, 323-330.
43. Tan HH, Ahmad AB (2018) Betta omega, a new species of black water fighting fish (Teleostei: Osphronemidae) from Malaysia. Raffles Bull Zool 66, 402-407.

44. Rainboth WJ, Vidthayanon C, Yen MD (2012) Fishes of the Greater Mekong Ecosystem with Species List and Photographic Atlas, Miscellaneous Publications, Ann Arbor.

45. Song YN, Xiao GB, Li JT (2016) Complete mitochondrial genome of the Siamese fighting fish (Betta splendens). Mitochondrial DNA A DNA Mapp Seq Anal 27, 4580-4581.

46. Prakhongcheep O, Muangmai N, Peyachoknagul S, Srikulnath K (2018) Complete mitochondrial genome of mouthbrooding fighting fish (Betta pi) compared with bubble nesting fighting fish (B. splendens). Mitochondrial DNA B Resour 3, 6-8.

47. Ponjarat J, Areesirisuk P, Prakhongcheep O, Dokkaew S, Sillapaprayoon S, Muangmai N, Peyachoknagul S, Srikulnath K (2019) Complete mitochondrial genome of two mouthbrooding fighting fishes, Betta apollon and B. simplex (Teleostei: Osphronemidae). Mitochondrial DNA B Resour 4, 672-674.

48. Worapong S, Farhan Ahmad S, Laopichienpong N, Suntronpong A, Pongsanarm T, Panthum T, Ariyaraphong N, Subpayakom N, et al (2020) Complete mitochondrial genome of Mahachai betta, Betta mahachaiensis (Teleostei: Osphronemidae). Mitochondrial DNA B Resour 5, 3077-3079.

49. Carey AN, Lyvers BH, Ferrill RN, Johnson RL, Dumaine AM, Sly BJ (2016) Development of Betta splendens embryos and larvae reveals variation in pigmentation patterns. Zygote 24, 396-400.

50. Krauss J, FrohnhÖfer HG, Walderich B, Maischein HM, Weiler C, Irion U, Nüsslein-Volhard C (2014) Endothelin signalling in iridophore development and stripe pattern formation of zebrafish. Biol Open 3, 503-509.

51. Kottler VA, Künstner A, Koch I, Flöenmeyer M, Langenecker T, Hoffmann M, Sharma E, Weigel D, Dreyer C (2015) Adenylate cyclase 5 is required for melanophore and male pattern development in the guppy (Poecilia reticulata). Pigment Cell Melanoma Res 28, 545-558.

52. Kottler VA, Koch I, FlÖtenmeyer M, Hashimoto H, Weigel D, Dreyer C (2014) Multiple pigment cell types contribute to the black, blue, and orange ornaments of male guppies (Poecilia reticulata). PLoS One 9, e85647.

53. Filby AL, Paull GC, Hickmore TF, Tyler CR (2010) Unravelling the neurophysiological basis of aggression in a fish model. BMC Genomics 11, ID 498.

54. Narvaes R, Martins de Almeida RM (2014) Aggressive behavior and three neurotransmitters: dopamine, GABA, and serotonin-A review of the last 10 years. Psychol Neurosci 7, 601-607. 